MATEC Web of Conferences 15, 01032 (2014)

DOI: $10.1051 /$ matecconf/ 20141501032

(C) Owned by the authors, published by EDP Sciences, 2014

\title{
Utilization of Palm Oil Fuel Ash and Rice Husks in Unfired Bricks for Sustainable Construction Materials Development
}

\author{
Saleh A.M ${ }^{1}$, Rahmat M.T ${ }^{2}$, Mohd Yusoff F.N ${ }^{3}$, Eddirizal N.E ${ }^{4}$ \\ ${ }^{1,2,3}$ Center of Construction, Faculty of Architecture, Planning and Surveying, UiTM Shah Alam \\ ${ }^{4}$ Department of Building, Faculty of Architecture, Planning and Surveying, UiTM Seri Iskandar, \\ Perak
}

\begin{abstract}
The production of sustainable construction component could prevent and control the pollution and environmental degradation in Malaysia. This is a key area in Malaysia's Green Strategies (Ministry of Science, Technology and the environment, 2002). This paper reports on the laboratory investigation to establish the potential of utilizing Palm Oil Fuel Ash (POFA) and Rice Husk (RH) in developing green construction components. Malaysian Palm Oil Council (MPOC) reported that currently Malaysia's contribution to world palm oil production is $39 \%$ and has taken $44 \%$ of world exports. Consequently it will increase the POFA production in palm oil manufacturing and this waste sometimes dispose in open area near the factory. On the other hand Malaysia also producing more $300 \mathrm{k}$ hectares of paddy production, thus rice husk is also a concern as an agricultural waste. The research objective is to study on the potential of utilizing of agricultural waste in developing of green bricks. This research involved laboratory investigations. In this research $2 \%-10 \%$ of POFA and $1 \%-5 \% \mathrm{RH}$ were used in the mix composition of the brick's weight. Addition of POFA was aimed to reduce the cement usage and RH was added to reduce sand in the bricks. The bricks were manually pressed in Materials Laboratory in Faculty of Architecture, Planning and Surveying, UiTM Shah Alam. The result showed that the addition of POFA and RH are able to reduce the density but in contrast the compressive strength were decrease compare to the control unit.
\end{abstract}

\section{Introduction}

Brick is one of the conventional construction component widely used. Sun-baked and fired clay bricks are conventionally used for mainstream masonry wall construction but they suffer from the rising price of energy usage and carbon dioxide emission [1]. The term of 'brick' is included process of mixing, preparing and moulding before it's slowly drying and been firing in an oven [2]. Uncontrolled increase in building material prices may affect construction period, the project cost and the end user. Concern shown by the Master Builders Association Malaysia (MBAM), Real Estate and Housing Developers' Association Malaysia (REHDA), Malay Contractors Association of Malaysia (PKMM) and India Contractors Association Malaysia (PKIM) on the prices of construction materials have recently caused by external pressure [3]. Higher demand for construction materials, shortage of raw materials and high price of energy will affect the increment cost of construction materials. 
Therefore research to reduce energy consumption and alternative for natural resources becoming a global issue in producing sustainable construction materials [4].

The utilization of waste in construction materials is not new. The addition of waste such as fly ash, blast furnace slag, phosphogypsum, recycled aggregates, red mud, Kraft pulp production residue, waste tea etc. in the production of sustainable construction components shown some success of research in each area of study [5]. There are five types of solid waste that been recycled and utilized for construction materials. Agro waste (organic) such as rice and wheat straw, saw mill waste, ground nut shell, jute, sisal, cotton stalk, vegetable residue have been recycled to produce cement boards, particle board, wall panels, roof sheets and other related construction components. Industrial waste (inorganic), mining/mineral waste, non hazardous waste and hazardous waste also used to produce bricks, blocks, wood substitute product as well as ceramic products.

Palm ash can be found either in black or dark gray [6]. This is very much influenced by the carbon content. Particles are also spherical and have sizes smaller than cement. As shown in the Table 1 , ash fineness was $519 \mathrm{~m}^{2} / \mathrm{kg}$ and its specific gravity is 2.22 . In terms of delicacy, Palm ashes are finer than Portland cement. Chemical content of $\mathrm{SiO}_{2}$ (43.6\%), $\mathrm{Al}_{2} \mathrm{O}_{3}(11.4 \%)$ and $\mathrm{Fe}_{2} \mathrm{O}_{3}(4.7 \%)$. Table 1 below shows the physical properties of OPC and POFA.

Table 1: Physical and Chemical Properties of OPC and POFA

\begin{tabular}{|l|c|c|}
\hline & OPC & POFA \\
\hline Physical Properties & 3.28 & 2.22 \\
Specific gravity & & \\
Chemical Analysis (\%) & 20.2 & 43.6 \\
Silicon dioxide $\left(\mathrm{SiO}_{2}\right)$ & 5.7 & 11.4 \\
Aluminium Oxide $\left(\mathrm{Al}_{2} \mathrm{O}_{3}\right)$ & 3.0 & 4.7 \\
Ferric Oxide $\left(\mathrm{Fe}_{2} \mathrm{O}_{3}\right)$ & 62.5 & 8.4 \\
Calcium Oxide $(\mathrm{CaO})$ & 2.6 & 4.8 \\
Magnesium Oxide $(\mathrm{MgO})$ & 1.8 & 2.8 \\
Sulphur Trioxide $\left(\mathrm{SO}_{3}\right)$ & 0.16 & 0.39 \\
Sodium Oxide $\left(\mathrm{Na}_{2} \mathrm{O}\right)$ & 0.87 & 3.5 \\
Potassium Oxide $\left(\mathrm{K}_{2} \mathrm{O}\right)$ & & \\
\hline
\end{tabular}

POFA does not contain sufficient nutrients for use as a fertilizer. Hence, it is mostly dumped into open fields near to the palm oil factories, thus causing environmental pollution and health hazard. In order to resolve these problems, several studies were conducted to examine the feasibility of using POFA in construction materials [6]. In Thailand, the palm oil fuel ash (POFA) has been utilized as a pozzolanic material in concrete [7]. On the other hand rice husk is an agricultural waste that can be easily obtained in mass quantity locally. Rice husk can be used for a variety of needs such as chemical industrial raw materials and building materials, energy / fuel, active charcoal and briquettes. According to Ahmad Fuad et. al. [8], currently a lot of agricultural waste (rice husk) can only be burned in the open outside the factory. The situation would threaten the environment and cause air pollution [9]. In general, rice husks or straw colour golden, 5-10 $\mathrm{mm}$ long and 2.5 to $5 \mathrm{~mm}$ wide.

Table 2: Chemical Composition Of Rice Husk

\begin{tabular}{l|c}
\hline Composition & Weight Percentage \\
\hline Cellulose & $35 \%$ \\
Hemicellulose & $25 \%$ \\
Lignin & $20 \%$ \\
Ash & $17 \%$ \\
Other chemical constituents & $3 \%$ \\
\hline
\end{tabular}

According to Sahed and Jog [10], rice husks constitute $20 \%$ of the total paddy produced. The percentages of chemical constituents in different biofibres are different. Generally, the fibers contain 
60 to $80 \%$ cellulose, 5 to $20 \%$ lignin, and up to $20 \%$ of moisture and according to Hattotuwa et. al. [11] as indicated in Table 2 below. Rice husk filler contains cellulose, hemicellulose, lignin ash and other chemical constituents [12].

Therefore research should rigorously look into the production of unfired Green Bricks manufacturing process that can utterly reduced carbon emission. Producing a sustainable construction component could prevent and control the pollution and environmental degradation which also one of the key area in Malaysia's Green Strategies [13]. Researches on utilizing wastes from industrial and agriculture have been made by incorporating these wastes into building or construction materials are a practical solution to the environment pollution [14].

\section{Experimental Procedures}

Materials gathered from the respective area and all materials were prepared and the mixing used both manually and mechanically using laboratory mixer. Material used in this research consist of laterite soil, sand, Ordinary Portland Cement (OPC), Palm Oil Fuel Ash (POFA) and Rice Husk (RH). Laboratory testing carried out according to EN772-1:2011 [15]

\section{a) Laterite Soil}

The laterite soil was kept under sheltered area as to control the moisture content in the soil. The sieve size used to strain soil is $12 \mathrm{~mm}$ diameter. Therefore, size of soil particle must below than $12 \mathrm{~mm}$ diameter. The soil used was reddish brown in colour and easy to get in Shah Alam.

\section{b) Sand}

The sand was prepared at to concrete laboratory (UiTM). Dry sand is preferred to be used for this specimen. The reason is to control the water contain in the brick. Therefore, sand will be left in the oven for the whole night under $100^{\circ} \mathrm{C}$ for temperature. Sand also will be sieved before use by using $6 \mathrm{~mm}$ sieve container.

\section{c) Ordinary Portland Cement (OPC)}

The cement used in this experiment was Ordinary Portland Cement as according to the British Standard specification [16] for the concrete works specification.

\section{d) Palm Oil Fuel Ash (POFA)}

Palm oil fuel ash (POFA) used in this experiment was taken Eng Hong Palm Oill Mill Sdn Bhd, Banting, Selangor. Ash actually produced from palm kernel burned as fuel in palm oil mill boiler. Ashes that will take were ash in grayish colour. The POFA dried in $110^{\circ} \mathrm{C}$ temperature of oven for 24 hour to control the rate of the moisture content. The ashes sieved by using $6 \mathrm{~mm}$ sieve container.

\section{e) Rice Husk (RH)}

Rice husk (RH) used in this experiment was taken from Dibuk Sdn Bhd, Perlis. Rice husk is the final result of the process of production of rice from rice plants. It is obtained through a process of grading which is rice paddy plants will be harvested using harvesting machines. Then rice paddy plants will be sent to the factory for process separate rice from the rice husk. The natural rice husk will be used for preparing specimen.

\subsection{Mix composition, sample preparation and testing}

The mix percentage used for control brick was $70 \%$ soils, $24 \%$ sand and $6 \%$ cement. The percentage of wastage allocate was $20 \%$ which to cover if there any spillage occur during handling means during lift material from mixer to pressed machine and also during pressing the bricks. Each constituent material quantity in total was soil $25 \mathrm{~kg}$, sand $8.4 \mathrm{~kg}$ and cement $1.6 \mathrm{~kg}$. Each group of specimens contained 10 numbers of bricks. The percentage of POFA were used from weight of 
cement is $2 \%, 4 \%, 6 \%, 8 \%$ and $10 \%$. Total quantity of POFA is $600 \mathrm{~g}$. The percentage of Rice Husk (RH) were used from weight of sand was $1 \%$ to $5 \%$. The total quantity of RH used was $1.20 \mathrm{~kg}$. Moisture content was controlled at $7 \%$ of the weight of the specimens.

Table 3: Quantity of POFA and RH

\begin{tabular}{|c|c|c|c|c|}
\hline Sample No & $\begin{array}{c}\text { RH Volume Fraction } \\
(\%)\end{array}$ & RH Quantity & $\begin{array}{c}\text { POFA Volume Fraction } \\
(\%)\end{array}$ & POFA Quantity \\
\hline S1 & $1 \%$ of sand $(8.0 \mathrm{~kg})$ & $80 \mathrm{~g}$ & $2 \%$ of cement $(2.0 \mathrm{~kg})$ & $40 \mathrm{~g}$ \\
S2 & $2 \%$ of sand $(8.0 \mathrm{~kg})$ & $160 \mathrm{~g}$ & $4 \%$ of cement $(2.0 \mathrm{~kg})$ & $80 \mathrm{~g}$ \\
S3 & $3 \%$ of sand $(8.0 \mathrm{~kg})$ & $240 \mathrm{~g}$ & $6 \%$ of cement $(2.0 \mathrm{~kg})$ & $120 \mathrm{~g}$ \\
S4 & $4 \%$ of sand $(8.0 \mathrm{~kg})$ & $320 \mathrm{~g}$ & $8 \%$ of cement $(2.0 \mathrm{~kg})$ & $160 \mathrm{~g}$ \\
S5 & $5 \%$ of sand $(8.0 \mathrm{~kg})$ & $400 \mathrm{~g}$ & $10 \%$ of cement $(2.0 \mathrm{~kg})$ & $200 \mathrm{~g}$ \\
\hline \multicolumn{2}{|r|}{ Total of quantity } & $1.20 \mathrm{~kg}$ & Total of quantity & $600 \mathrm{~g}$ \\
\hline
\end{tabular}

Table 4: Quantity of POFA and RH Used

\begin{tabular}{|c|c|c|c|c|c|c|}
\hline $\begin{array}{c}\text { Sample } \\
\text { Label }\end{array}$ & Quantity & $\begin{array}{c}\text { Laterite 70\% } \\
(\mathrm{kg})\end{array}$ & $\begin{array}{c}\text { Sand 24\% } \\
(\mathrm{kg})\end{array}$ & $\begin{array}{c}\text { Cement 6\% } \\
(\mathrm{kg})\end{array}$ & $\begin{array}{c}\text { POFA \% from } \\
\text { cement }(\mathrm{kg})\end{array}$ & $\begin{array}{c}\text { RH \% from } \\
\text { sand }(\mathrm{kg})\end{array}$ \\
\hline CS & 10 & 25 & 8.4 & 1.6 & - & - \\
\hline S1 & 10 & 25 & 8.32 & 1.56 & $2(0.04)$ & $1(0.08)$ \\
\hline S2 & 10 & 25 & 8.24 & 1.52 & $4(0.08)$ & $2(0.16)$ \\
\hline S3 & 10 & 25 & 8.16 & 1.48 & $6(0.12)$ & $3(0.24)$ \\
\hline S4 & 10 & 25 & 8.08 & 1.44 & $8(0.16)$ & $4(0.32)$ \\
\hline S5 & 10 & 25 & 8.00 & 1.40 & $10(0.20)$ & $5(0.40)$ \\
\hline
\end{tabular}

\subsection{Sample Preparation}

The bricks were pressed in using hydraulic pressing machine. The processes of material mixing were carried out in 2 steps by using mini mixer and hand shovel. All the mixing processes were taken about 10 minutes for each type of samples. After mixing, the materials were poured out and mixed for another 10 minutes by hand to ensure the materials were homogeneous. Finally, the materials were loaded into the mould and hydraulically pressed with 300 Psi. The bricks samples were arranged on pallet and wrapped with cling-film. This is to avoid rapid drying of the sample. The bricks were kept air dry for 60 days before testing at the age of 7, 28 and 60 days.

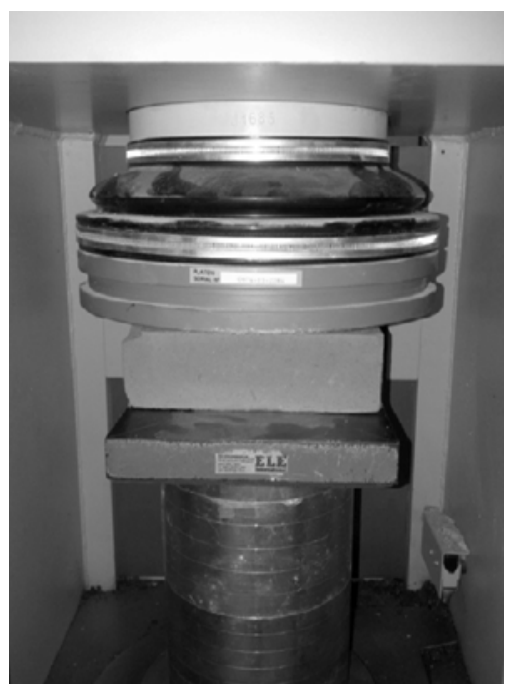

Figure 1: Compressive Strength Test for Brick 


\section{Results and Discussions}

\subsection{Density}

This research aimed to study the effect of adding RH to the brick's physical properties; the weight and density of the brick. Rice husk were used to replace sand in a purpose to enlighten the brick. According to the data obtained from the results, the specimen's weight at 28 and 60 day were decreased with increasing of RH content. This is thought to be the specific gravity of RH was lower than the natural sand. The lightest brick at day 60 was $2.4 \mathrm{~kg}$ for the S5 mixture with density of 1.675 $\mathrm{kg} / \mathrm{m}^{3}$. The density of brick was calculated by dividing the average weight with volume.

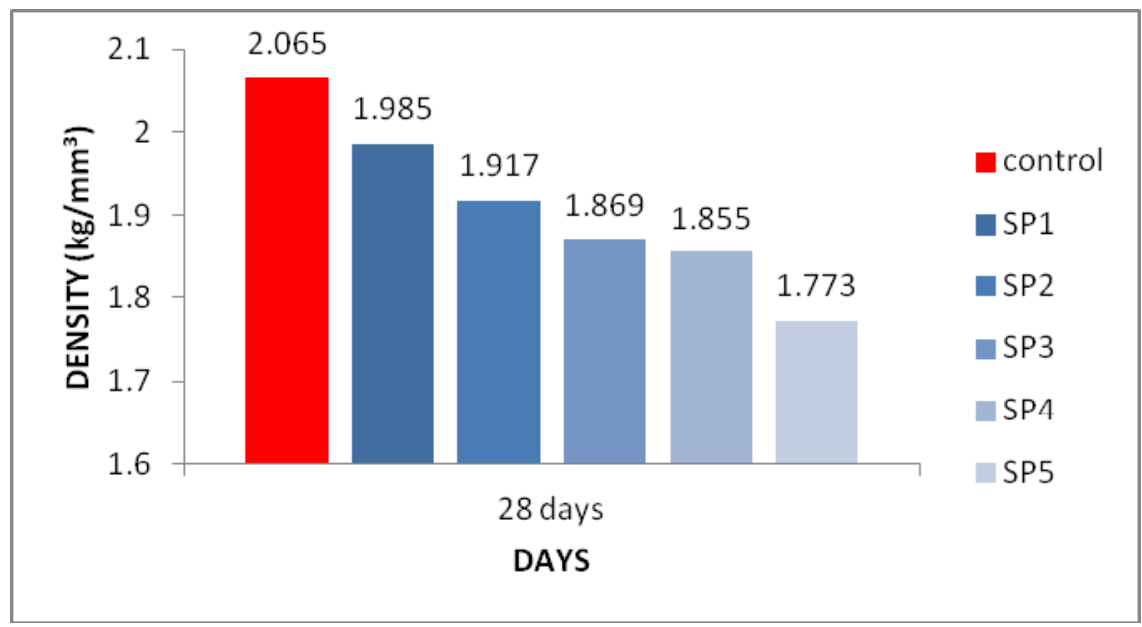

Figure 2: Density of Brick on 28 days

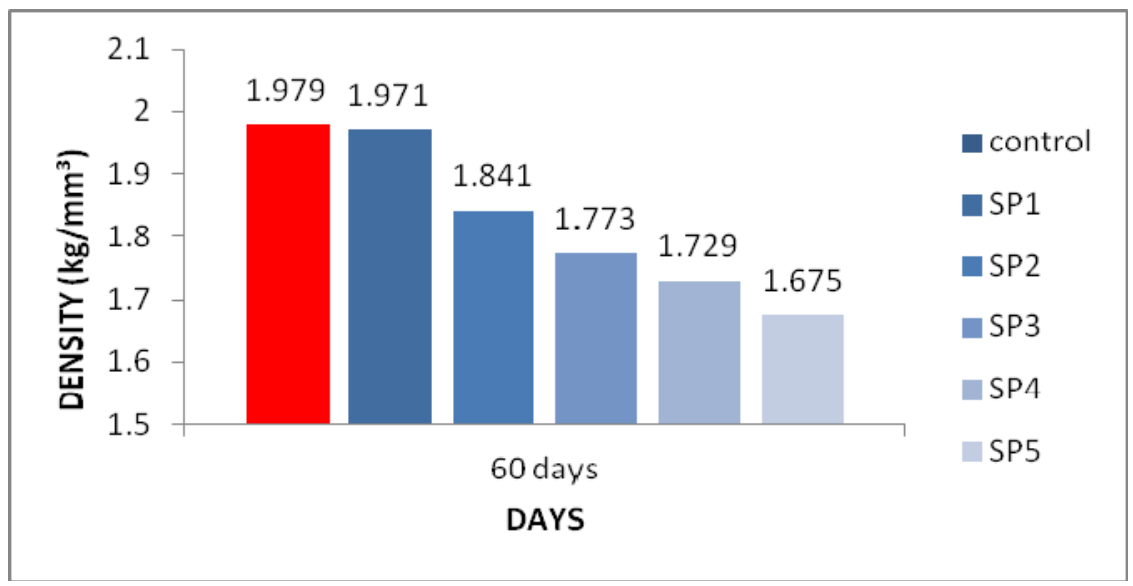

Figure 3: Density of Brick on 60 days

Figure 2 and 3 shows the density of the bricks at 28 and 60 days respectively. The overall results showed that the density of the bricks decreased with an increase in RH content. Addition of RH would contribute to the lightweight property of the bricks. The density per unit volume of RH brick is much lighter compared to sand as in control brick. This indicates that RH can be used as a material to replace sand in brick making to achieve objective of lightweight brick production. 
Table 5: Relationship between the Weight and the Amount of RH

\begin{tabular}{|c|c|c|c|c|c|c|c|}
\hline Sample & Description & $\begin{array}{c}\text { Weight } \\
\text { Of RH }\end{array}$ & $\begin{array}{c}\text { Volume } \\
\left(\mathrm{m}^{3}\right)\end{array}$ & $\begin{array}{c}\text { Averange } \\
\text { Weight Of } \\
\text { Brick 28 Days } \\
(\mathrm{kg})\end{array}$ & $\begin{array}{c}\text { Averange } \\
\text { Weight Of } \\
\text { Brick 60 Days } \\
(\mathrm{kg})\end{array}$ & $\begin{array}{c}\text { Density of } \\
\text { Brick 28 } \\
\text { days } \\
\left(\mathrm{Kg} / \mathrm{m}^{3}\right)\end{array}$ & $\begin{array}{c}\text { Density of } \\
\text { Brick 60 } \\
\text { days } \\
\left(\mathrm{Kg} / \mathrm{m}^{3}\right)\end{array}$ \\
\hline CS & $\begin{array}{c}\text { Brick with } \\
\text { 0\% of RH }\end{array}$ & 0 & 1.43 & 2.953 & 2.83 & 2.065 & 1.979 \\
\hline S1 & $\begin{array}{l}\text { Brick with } \\
\text { 1\% of RH }\end{array}$ & 80 & 1.43 & 2.838 & 2.819 & 1.985 & 1.971 \\
\hline S2 & $\begin{array}{l}\text { Brick with } \\
\text { 2\% of RH }\end{array}$ & 160 & 1.43 & 2.742 & 2.633 & 1.917 & 1.841 \\
\hline S3 & $\begin{array}{l}\text { Brick with } \\
\text { 3\% of RH }\end{array}$ & 240 & 1.43 & 2.672 & 2.536 & 1.869 & 1.773 \\
\hline S4 & $\begin{array}{l}\text { Brick with } \\
\mathbf{4 \%} \text { of RH }\end{array}$ & 320 & 1.43 & 2.652 & 2.472 & 1.855 & 1.729 \\
\hline S5 & $\begin{array}{l}\text { Brick with } \\
\text { 5\% of RH }\end{array}$ & 400 & 1.43 & 2.536 & 2.395 & 1.773 & 1.675 \\
\hline
\end{tabular}

The relationship between the weight and the percentage of $\mathrm{RH}$ and the relationship between density and the percentage of RH is shown in the Table 5 .

Table 6: Result of Compressive Strength

\begin{tabular}{|c|c|c|c|c|}
\hline \multirow{2}{*}{ Sample } & \multirow{2}{*}{ Specimen } & \multicolumn{3}{|c|}{ Compressive Strength $\left(\mathrm{N} / \mathrm{mm}^{2}\right)$} \\
\hline & & 7 days & 28days & 60days \\
\hline $\mathrm{CS}$ & Brick with $0 \%$ of POFA \& RH & 4.500 & 5.280 & 6.196 \\
\hline S1 & Brick with $2 \%$ of POFA \& $1 \%$ of RH & 9.024 & 8.727 & 8.425 \\
\hline S2 & Brick with $4 \%$ of POFA \& $\mathbf{2 \%}$ of $\mathrm{RH}$ & 7.390 & 7.337 & 7.191 \\
\hline S3 & Brick with $6 \%$ of POFA \& $\mathbf{3 \%}$ of RH & 4.584 & 4.128 & 3.407 \\
\hline S4 & Brick with $8 \%$ of POFA \& $4 \%$ of RH & 3.859 & 3.809 & 3.608 \\
\hline S5 & Brick with $10 \%$ of POFA \& $\mathbf{5 \%}$ of RH & 2.666 & 2.380 & 2.271 \\
\hline
\end{tabular}

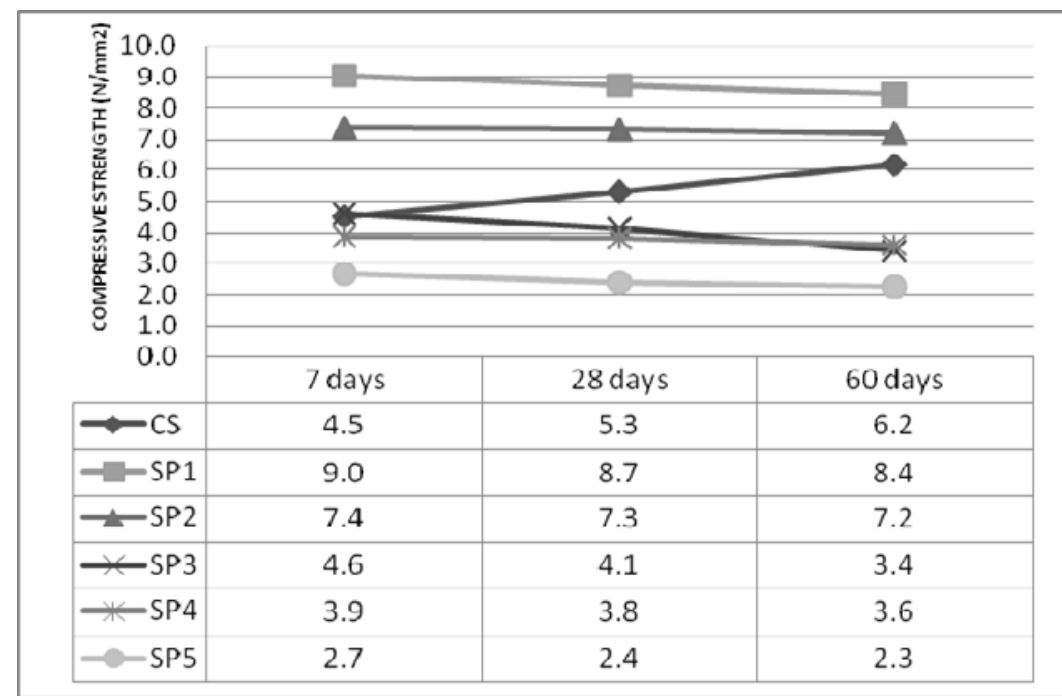

Figure 4: Compressive Strength of different mixture of POFA \& RH 


\subsection{Compressive Strength}

Figure 4 shows the compressive strength of different mixture of bricks specimens. The strength of the control specimens increased as the curing period increased. The results also recorded that the compressive strength for SP2 and SP3 mixture were higher strength than control brick at all curing age 7, 28 and 60 days. The Strength of SP1 and SP2 at 7 days was $9.024 \mathrm{~N} / \mathrm{mm}^{2}$ and $7.390 \mathrm{~N} / \mathrm{mm}^{2}$. The same pattern of result recorded at 28 and 60 days. Figure 5 shows crushed brick after Compressive Strength test. However, the result indicated that replacement of cement and sand with POFA and RH decreased in strength while the control brick strength was increased. For SP3, the result show at the beginning was higher than control brick which is $4.584 \mathrm{~N} / \mathrm{mm}^{2}$ compare to 4.500 $\mathrm{N} / \mathrm{mm}^{2}$, however the strength was decreased as the curing period increased from $4.128 \mathrm{~N} / \mathrm{mm}^{2}$ at 28 days to $3.407 \mathrm{~N} / \mathrm{mm}^{2}$ at 60 days which is lower than control brick. The decreased in compressive strength with increasing percentage of POFA and RH were also observed by [17] in his investigation on effect of Rice Husk and Rice Husk Ash to properties of bricks. This is probably because higher porosity and low bulk density specimens were produced. However replacement of $2 \%$ and $4 \%$ of POFA and $1 \%$ and $2 \%$ of RH (S1 and S2) gave higher strength at early stage which is better than $0 \%$ of POFA and RH. The best composition mix of POFA and RH in sun baked bricks is $2 \%$ of POFA and $1 \%$ of $\mathrm{RH}(\mathrm{S} 1)$ even though the strength was declining as the curing period increased but the strength is higher than control brick.

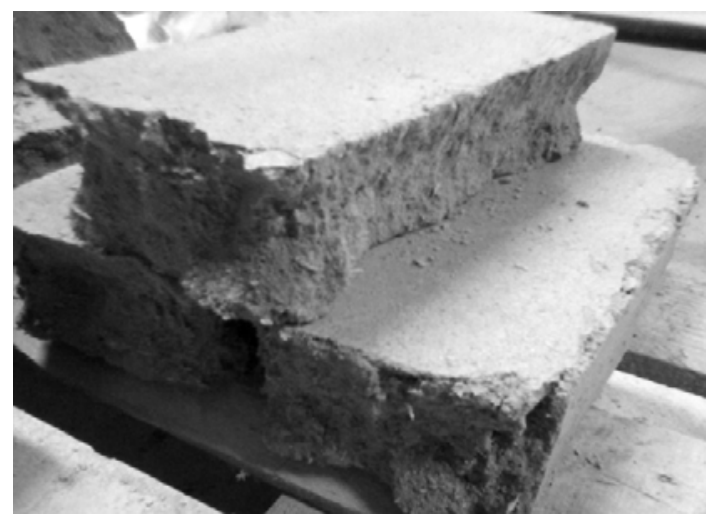

Figure 5: Crushed brick after Compressive Strength Test

\section{Conclusion}

From the laboratory experiments the increase percentage of POFA and RH in the mixed design of laterite brick reduced the density and the compressive strength. However the maximum percentage of POFA and RH can be use in mix proportion of bricks is $4 \%$ of POFA and $2 \%$ of RH to get comparable strength to the control sample. The best combination of POFA and RH in this research was $\mathrm{S} 1$ that showed higher compressive strength than control brick which is $8.425 \mathrm{~N} / \mathrm{mm}^{2}$. In term of Lightweight brick production, replacement of sand with RH show the better result compared to when POFA was used. $5 \%$ of RH in the mixture contribute to lower weight which is $2.395 \mathrm{~kg}$ compared to control specimen which is $2.83 \mathrm{~kg}$ with density of $1.675 \mathrm{~kg} / \mathrm{m}^{3}$. The end product from this research will reduce the consumer cost as the bricks are utilising the agricultural waste materials. Thus POFA before this, were disposed widely to the environment it will be recycled to produce sustainable materials. Recommendation for future research in developing green bricks by using different water cement ratio, different industrial waste. This research adopting curing time up to 60 days, by prolong the curing time the different result may be achieved. 


\section{Acknowledgement}

The authors would like to thank the Universiti Teknologi MARA (UiTM) for funding the research, via the Research Intensive Faculty (RIF) Programme (Project Code: 600-RMI/DANA 5/3/RIF (280/2012). The authors finally acknowledge the research and undergraduate students of BSc Construction Management (Hons) and staffing resources provided by the Faculty of Architecture, Planning and Surveying, UiTM.

\section{References}

1. Muntohar, A. (2011). Engineering characteristics of the compressed-stabilised earth brick. Construction Building Materials 25: 4215-4220.

2. Cultrone, G. \& Sebastian, E. (2008). "Fly ash addition in clayey materials to improve the quality of solid brick".Department of Mineralogy and Petrology, Faculty of Science, Granda University.Pp 2,3.

3. Master Builders Association Malaysia (2007)."Rising prices of building material will hamper construction industry”.Retrieved September 20, 2012

4. Safiuddin, M. (2010). Utilization of Solid Wastes in Construction Materials. Physical Sciences , 1952-1963

5. Safiuddin, M., Jumaat, M.Z., Salam, A., \&Hafizan, M. (2010). "Best use of palm oil fuel ash". The Independent. Retrieved Sept 26, 2012 from The Independent,

6. Aminudin, E. (2010), "Engineering Properties of POFA Cement Brick". UniversitiTeknologi Malaysia: Thesis Master

7. Tangchirapat, W.,Saeting, T.,Jaturapitakkul, C.,Kiattikomol, K. \& Siripanichgorn, A. (2006). "Use of waste ash from palm oil industry in concrete".Department of Civil Engineering, King Mongkut's University of Technology Thornburi, Thailand.

8. Ahmad Fuad, M.Y., Zaini, M.J., Jamaludin, M., Mohd Ishak, Z.A. and Mohd Omar, A.K.(1994). Determination of Filler Content in Rice Husk Ash and Wood-Based Composites by Thermogravimetric Analysis, Journal of Applied Polymer Science 51: 1875-1882

9. Suri, R.S. (2009). “Komposit Poliester Tak Tepu - Sekam Padi: Kesan Pencuacaan Terhadap Sifat Mekanikal Komposit”. Universiti Sains Malaysia.

10. Saheb \& Jog (1999), "Natural Fibre Polymer Composite : A Review", Advances in Polymer Technology, Vol. 18, No. 4, 351-363.

11. Hattotuwa G.B. Premalal, H. Ismail (2002), “A. Baharin Comparison of the mechanical properties of rice husk powder filled polypropylene composites with talc filled polypropylene composites", Polymer Testing 21: 833-83

12. Ministry of Science, Technology and Environment, Malaysia. (2002). National Policy on the Environment. Malaysia: Ministry of Science, Technology and Environment.

13. Ministry of Science, Technology and Environment, Malaysia. (2002). National Policy on the Environment. Malaysia: Ministry of Science, Technology and Environment

14. S.P. Raut, R. R. (2011). Development of sustainable construction material using industrial and agricultural solid waste: A Review of waste-create bricks. Construction and Building Materials 25: 4037-4042.

15. EN 772-1 (2011), Methods Of Test For Masonry Units. Determination Of Compressive Strength, British Standard Instituition

16. BS 812-2: 1995 (1995) Testing For Aggregates, Methods For Determination Of Density, British Standard Instituition

17. Sutas, J., Mana, A. \& Pitak, L. (2011). "Effect of Rice Husk and Rice Husk Ash to Properties of Bricks. Procedia Engineering 32 (2012) 1061 - 1067 